\title{
NATRIURESIS AFTER CARDIOPULMONARY BYPASS: RELATIONSHIP TO URODILATIN, ATRIAL NATRIURETIC FACTOR, ANTIDIURETIC HORMONE, AND ALDOSTERONE
}

Jens Sehested, $\mathrm{MD}, \mathrm{PhD}^{\mathrm{a}}$

Beate Wacker, $\mathrm{MD}^{\mathrm{a}}$

Wolf-Georg Forssmann, MD, $\mathrm{PhD}^{\mathrm{b}}$

Erni Schmitzer ${ }^{\mathrm{a}}$
Objective: Recent studies suggest that urodilatin from the kidneys rather than atrial natriuretic factor from the heart is the more important member of the family of natriuretic peptides involved in the normal regulation of renal sodium and water excretion. We thus examined the relationship between natriuresis, urodilatin, and atrial natriuretic factor in patients after cardiopulmonary bypass, a procedure known to increase levels of atrial natriuretic factor significantly. Methods: Excretion rates of sodium and water were correlated with the excretion of urodilatin and with circulating levels of atrial natriuretic factor, antidiuretic hormone, aldosterone, and plasma renin activity during a period of 16 hours in 12 patients having had coronary artery bypass operations and with approximately a $\mathbf{4 0 0 \%}$ elevation in levels of atrial natriuretic factor. Results: Natriuresis did not correlate with atrial natriuretic factor, antidiuretic hormone, aldosterone, or plasma renin activity. Excretion rates of urodilatin, however, correlated significantly with excretion rates of sodium $(r=$ $0.74, p=0.03$, urine flow $(r=0.83, p=0.01$, and with levels of serum sodium ( $r=0.82, p=0.01)$. Conclusion: These results suggest an important role for urodilatin, greater than that of atrial natriuretic factor, in the regulation of renal excretion of sodium and water after cardiopulmonary bypass surgery. (J Thorac Cardiovasc Surg 1997;114:666-71)
$T^{\text {ton }}$ he most recently isolated member of the family of natriuretic-vasorelaxant peptides (ANF-[95-126] or CDD[ANP-95-126]), named urodilatin, ${ }^{1}$ is probably produced within the nephron by different posttranslational processing of the prohormone atrial natriuretic factor (ANF)-(1-126). ${ }^{2}$

By intravenous infusion, urodilatin has greater natriuretic effects than ANF-(99-126) (ANF) in normal human beings, ${ }^{3}$ in experimental animals, ${ }^{4,5}$ and in experimental models of congestive heart failure. ${ }^{6,7}$ This difference in natriuretic potency has been explained by differences in clearance mechanisms: whereas urodilatin is removed from the circulation mainly by clearance receptors, ANF is

From the Section of Clinical Physiology, Department of Cardiac Surgery, Deutsches Herzzentrum Berlin, ${ }^{a}$ and Niedersächsisches Institut für Peptid-Forschung, ${ }^{\mathrm{b}}$ Hannover, Germany.

Received for publication Sept. 26, 1996; revisions requested May 16, 1997; revisions received June 5, 1997; accepted for publication June 6, 1997

Address for reprints: Jens Sehested, MD, PhD, Deutsches Herzzentrum Berlin, Augustenburger Platz 1, D-13353 Berlin, Germany.

Copyright (c) 1997 by Mosby-Year Book, Inc.

$0022-5223 / 97 \$ 5.00+0 \quad \mathbf{1 2 / 1 / 8 3 7 9 2}$ cleared by both clearance ANF receptors and the enzyme neutral endopeptidase. ${ }^{8,9}$ Although of considerable therapeutic interest, the value of these studies for understanding the physiologic importance of urodilatins may well be more difficult to extract, because the peptide is only found in urine. ${ }^{10}$

Primarily based on correlation studies, recent reviews further suggest that in human beings, urodilatin, rather than ANF from the heart, might be the more important member of the ANF family involved in the regulation of renal sodium excretion. ${ }^{11-13}$

So far, however, studies in human beings have included only healthy subjects with normal levels of circulating ANF. It is thus uncertain whether a better correlation exists between renal function and urodilatin excretion than between renal function and levels of ANF when ANF values are very high. Because previous studies have suggested that ANF is involved in the not yet fully understood effects of cardiopulmonary bypass (CPB) on renal function, ${ }^{14,15}$ and because ANF increases significantly in response to this procedure, ${ }^{14,15}$ we examined the relationship between renal function (natriuresis, urine flow), urodilatin, ANF, antidiuretic hormone 
$(\mathrm{ADH})$, aldosterone, plasma renin activity (PRA), cortisol, serum sodium, plasma cyclic guanosine monophosphate, and hemodynamics in patients having had CPB operations approximately 24 hours earlier.

\section{Methods}

Subjects. Twelve patients having had coronary bypass graft operations (five women and seven men, aged 42 to 73 years) were studied. All patients gave their informed consent according to the Declaration of Helsinki, and the study was approved by the ethical committee of the hospitals. Circulating hormone levels in patients were compared with those of 10 healthy control subjects (five women and five men, aged 27 to 73 years). Because of the risk of infection associated with bladder catheterization in healthy subjects, no urine parameters were obtained from the control subjects. The patients were supported by CPB for an average of $59.1 \pm 5.3$ minutes (range 34 to 91 minutes). They were all cooled, and the aorta was crossclamped for $28 \pm 2.3$ minutes (range 18 to 47 minutes). The study began $30.4 \pm 0.6$ hours after CPB was stopped (range 26 to 32 hours). None of the patients had reoperations.

Study design. Experimental investigations suggest that cardiac baroreceptors are involved in the regulation of urodilatin release. ${ }^{16}$ Because most anesthetics influence the function of such receptors, ${ }^{17}$ we studied the patients during the twenty-fourth to forty-eighth postoperative hours to assure that little or no anesthetic remained in the patients. This protocol further reduced the influence of drugs with cardiovascular (and thus renal) action, frequently administered in the early postoperative period. Thus, apart from an intravenous dosage of furosemide to eight patients to maintain a high urinary output, no drugs were given during the study.

All patients had a urinary catheter and a central venous catheter through which central venous pressure (CVP) was measured and blood samples were drawn. The patients remained in the supine position during the entire study period. The patients were transferred to the ward from the intensive care unit around 11 AM. The study began at 6 PM, after the patients had had supper, and was terminated 16 hours later at $10 \mathrm{AM}$, when catheters were removed. For the duration of the study, urine flow and urinary electrolyte excretion were monitored at 2-hour intervals, and the urine was sampled for urodilatin determination. Every 2 hours blood was drawn for hormone determinations, and blood pressure (sphygmomanometry), heart rate, and CVP were measured. No dietary restrictions were made. The control subjects were studied in the afternoon. Blood was sampled through an antecubital venous catheter after 2 to 3 hours of supine rest. All blood and urine was sampled in prechilled tubes, immediately spun for 10 minutes at $3000 \mathrm{rpm}$ and $4^{\circ} \mathrm{C}$, and the supernatants were frozen at $-80^{\circ} \mathrm{C}$.

Determinations. Circulating hormones were determined by commercial radioimmunoassays as previously described $^{18}$ : ANF (Peninsula, Belmont, Calif.) after C-18 extraction, aldosterone (Sorin, Saluggia, Italy), PRA
(NEN, Billerica, Mass.), and cortisol (Biermann, Bad Nauheim, Germany). Sensitivity, intraassay, and interassay variability for $\mathrm{ADH}$ and melatonin (Nichols, Wijchen, The Netherlands) were $1.3 \mathrm{pg} / \mathrm{ml}, 6.7 \%$, and $6.9 \%$ and 3 $\mathrm{pg} / \mathrm{ml}, 5.9 \%$, and $8 \%$, respectively. With the exception of $\mathrm{ADH}$, which was determined in heparinized plasma, all hormones were measured in plasma treated with ethylenediaminetetraacetic acid (with aprotinin [Bayer, Leverkusen, Germany], added for ANF). Urodilatin was determined from ethanol-extracted urine treated with ethylenediaminetetraacetic acid by a specific antibody not cross-reacting with ANF, as recently described. ${ }^{19}$ Sensitivity was $7 \mathrm{pmol} / \mathrm{L}$, and intraassay and interassay variabilities were $8 \%$ and $12 \%$, respectively. Concentrations of sodium in urine and in serum were measured with the use of ion-selective electrodes (Na-K Analyzer 614, CIBACorning, Fernwald, Germany, and Hitachi 717 AutoAnalyzer, Boehringer, Mannheim, Germany, respectively). The assay for measuring cyclic guanosine monophosphate has previously been described in detail. ${ }^{20}$

Statistics. Friedman's test and Wilcoxon's test with the method of Bonferroni were used for testing for circadian variability. Wilcoxon's test was used for comparisons within a group, the Mann-Whitney test to compare patients with control subjects, and Pearson's least square method for the correlation analyses, using the statistical program of NCSS (Hintze, Kaysville, Utah). The level of statistical significance was set at $p<0.05$. The designation $p=$ NS indicates "not significant." Values are presented as means \pm standard error. Urine variables are given as excretion rates in units per minute.

\section{Results}

Figs. 1 and 2 show the excretion rates of urodilatin, urine, and sodium, serum levels of sodium, and the hormone levels in plasma during the eight study periods. Neither ANF (Fig. 3), aldosterone, ADH, PRA, nor cortisol showed any significant correlation with either urine flow or sodium excretion (all $p=$ NS). The excretion rates of urodilatin, however, correlated significantly with excretion rates of so$\operatorname{dium}(r=0.74, p=0.03)$, with urine flow $(r=0.83$, $p=0.01$ ) (Fig. 3), and with levels of serum sodium $(r=0.82, p=0.01)$. CVP further correlated with sodium excretion $(r=0.87, p=0.005)$. The significant correlations persisted after omission of the furosemide-stimulated values: urodilatin versus sodium excretion: $r=0.78, p=0.02$; urodilatin versus urine flow: $r=0.77, p=0.03$. Plasma levels of cyclic guanosine monophosphate correlated neither with levels of ANF nor with excretion rates of urodilatin (both $p=\mathrm{NS}$ ).

The hemodynamic parameters (blood pressure, heart rate, and CVP) were remarkably stable during the study (Fig. 2), showing no indication of circadian variability (all $p=\mathrm{NS}$ ). Whereas mean levels of ANF of the individual patients did not correlate with 


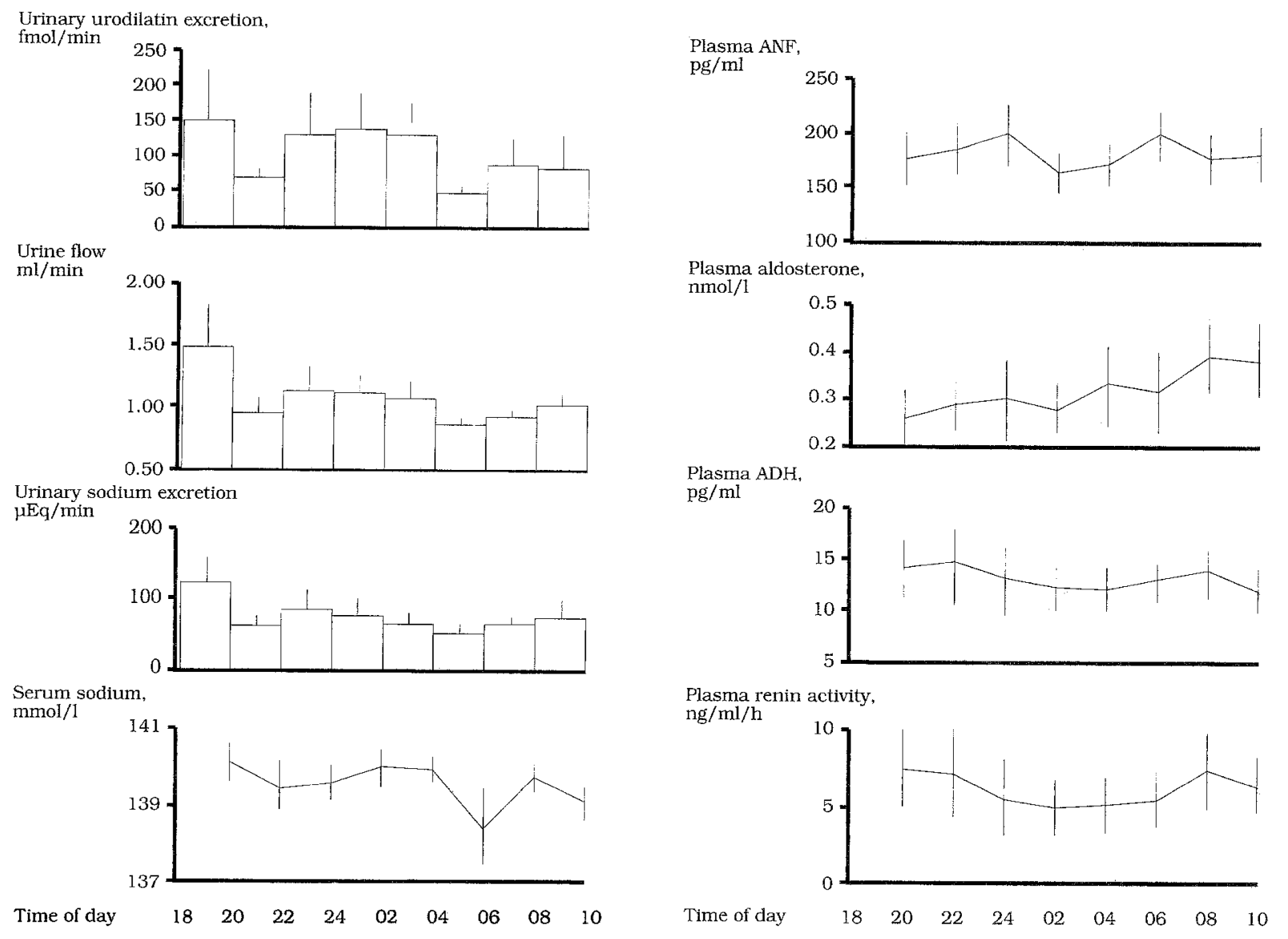

Fig. I. Renal excretion rates of urodilatin, urine, and sodium, and serum/plasma levels of sodium, ANF, aldosterone, $\mathrm{ADH}$, and PRA during the eight 2-hour periods in 12 patients studied $30.4 \pm 0.6$ to $46.4 \pm$ 0.6 hours after CPB was stopped. Means \pm standard errors.

mean values of CVP or blood pressure ( $p=$ NS), the mean excretion rates of urodilatin showed a significant correlation with CVP $(r=0.62, p=0.03)$ and with diastolic blood pressure $(r=0.76, p=0.005)$.

With the exception of aldosterone, plasma hormone levels were significantly higher than in the control subjects: ANF $179 \pm 21$ versus $45 \pm 5 \mathrm{pg} / \mathrm{ml}$ $(p=0.0001), \mathrm{ADH} 13.4 \pm 2.3$ versus $2.6 \pm 0.4 \mathrm{pg} / \mathrm{ml}$ $(p=0.0001)$, PRA $6.8 \pm 2.9$ versus $1.0 \pm 0.2 \mathrm{ng} / \mathrm{ml}$ per hour $(p=0.0006)$, and aldosterone $0.31 \pm 0.07$ versus $0.20 \pm 0.04 \mathrm{nmol} / \mathrm{L}(p=\mathrm{NS})$.

Compared with preoperative values, serum creatinine levels during the study were unchanged (1.1 \pm 0.05 vs $1.18 \pm 0.08 \mathrm{mg} / \mathrm{dl}, p=\mathrm{NS}$ ); serum levels of urea were slightly elevated $(34.5 \pm 2.1$ vs $47.6 \pm 3.3$ $\mathrm{mg} / \mathrm{dl})$. No patients had renal insufficiency. During the study, patients lost $627 \pm 109 \mathrm{gm}$ in weight. This weight loss did not correlate with urodilatin excretions or with ANF levels (both $p=\mathrm{NS}$ ).

The intravenous administration of furosemide caused a short-lived increase in urine flow in all $(1.04 \pm 0.13$ to $2.14 \pm 0.46 \mathrm{ml} / \mathrm{min}, p=0.01)$; the excretion rate of urodilatin dropped in all but two patients $(89 \pm 29$ vs $65.3 \pm 19.1 \mathrm{fmol} / \mathrm{min})$. This decrease, however, did not reach statistical significance $(p=\mathrm{NS})$.

Plasma cortisol levels did not show the typical steep rise from a midnight nadir, but remained elevated at values around $600 \mathrm{nmol} / \mathrm{L}$. Therefore, to check for a general paralysis of circadian oscillators in this group of patients who had been newly operated on, we measured levels of melatonin in properly handled remnant plasma samples. Fig. 2 shows a normal profile for plasma melatonin with a significant peaking around $4 \mathrm{AM}(p=0.008)$.

\section{Discussion}

Our data show that even during the postoperative period of sustained, significantly elevated levels of ANF (ADH and PRA), urodilatin excretion corre- 
Blood pressure, $\mathrm{mmHg}$

Heart rate $b / \mathrm{min}$ (HR)

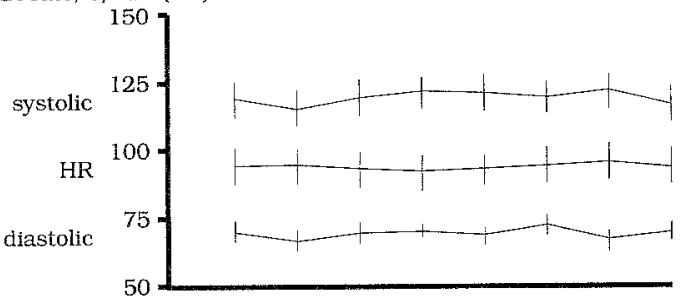

Central venous pressure, $\mathrm{mmHg}$

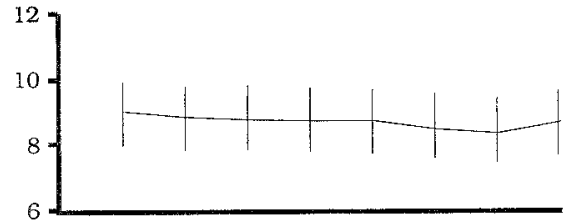

Plasma melatonin, pg/ml

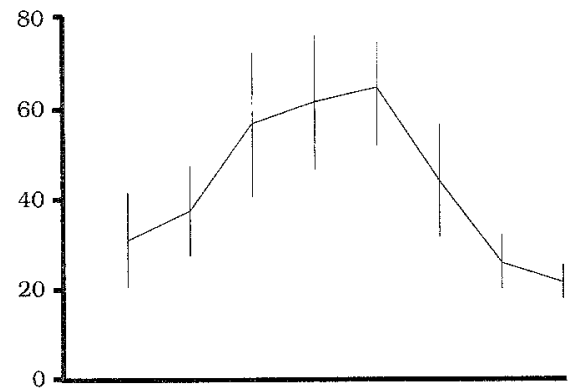

Plasma Cortisol,

nmol/1

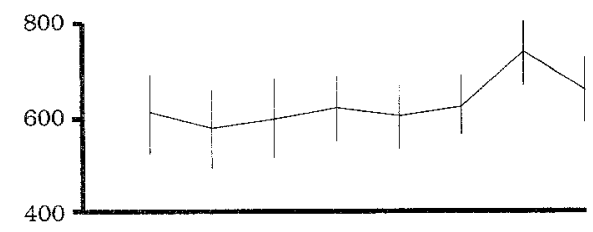

Time of day

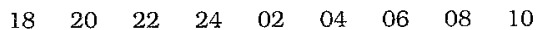

Fig. 2. Systolic and diastolic blood pressures, heart rate, CVP, plasma levels of melatonin, and cortisol (top to bottom) during the eight 2-hour periods in 12 patients studied $30.4 \pm 0.6$ to $46.4 \pm 0.6$ hours after CPB was stopped. Means \pm standard errors.

lates better with excretion rates of sodium and urine than do plasma levels of ANF, ADH, aldosterone, and PRA. These results agree with those of Drummer and associates, ${ }^{21}$ who showed that the excretion of urodilatin closely paralleled circadian urinary excretion of sodium and urine in six normal men, as well as during acute volume loading with saline solution.

Inasmuch as a statistical correlation is not evidence of cause or effect, the significant positive correlation between excretion rates of urodilatin
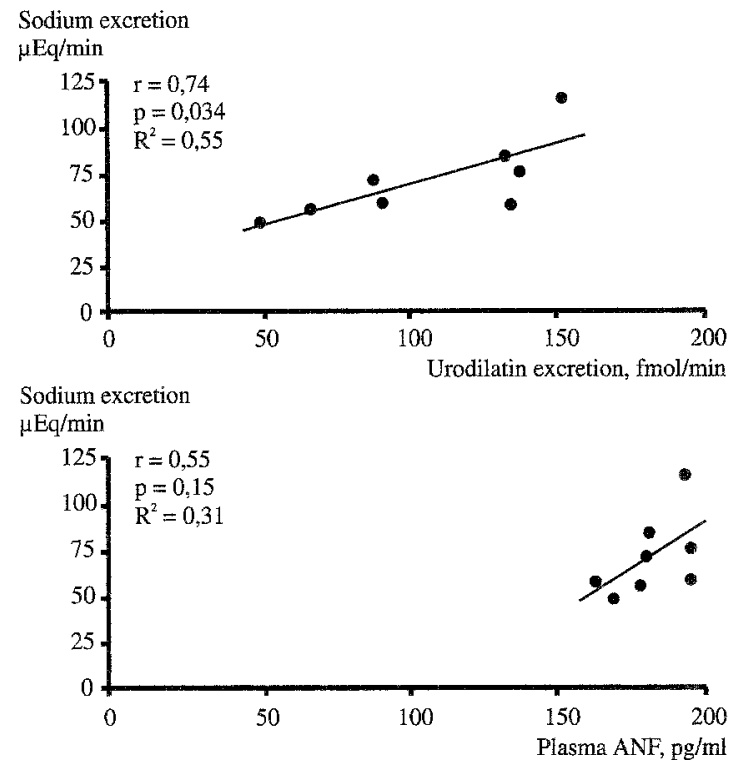

Urine flow $\mathrm{ml} / \mathrm{min}$

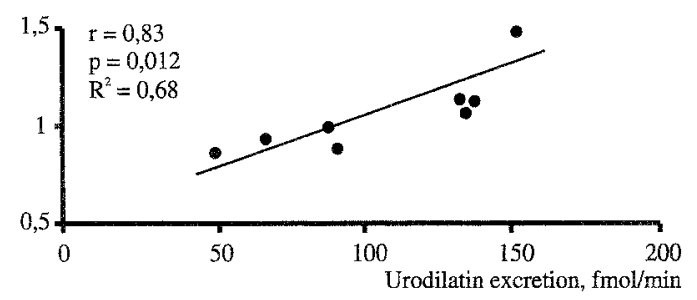

Urine flow

$\mathrm{ml} / \mathrm{min}$

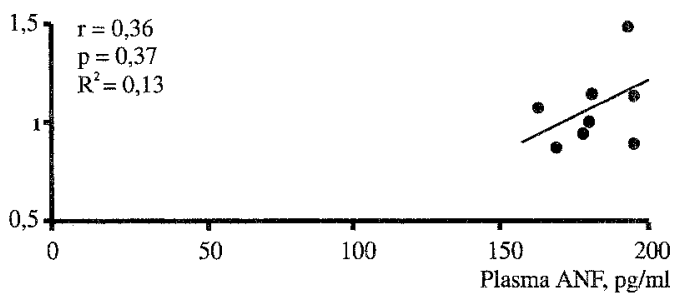

Fig. 3. Correlations between sodium and urodilatin excretions, sodium excretion and plasma levels of ANF, urine flow and urodilatin excretions, and urine flow and plasma levels of ANF (top to bottom).

and urine raises the question of a "washout" phenomenon. This, however, seems not to be the case, because furosemide increased urine flow in all eight patients but induced a drop, although statistically insignificant, in urodilatin excretion. It is thus unlikely that a significant correlation is due to urodilatin passively following urine flow.

Although the factors that regulate synthesis and release of urodilatin remain obscure, ${ }^{11}$ studies by Goetz and coworkers ${ }^{16}$ have suggested that cardiac nerves modulate the excretion of urodilatin. Left 
atrial distention increased urinary sodium and urodilatin excretion and plasma ANF in cardiac innervated dogs, whereas atrial distention, after cardiac denervation, caused an increase in ANF alone. The rise in diuresis and urodilatin excretion after an infusion of saline solution, however, did not appear to depend on intact cardiac innervation. ${ }^{16}$ The significantly better correlation in the present study between individual mean levels of urodilatin excretion and mean values of CVP (and diastolic blood pressure), than between these two parameters and plasma ANF, are in line with the results of the aforementioned experiments and with the results from human subjects exposed to an increase in central blood volume through water immersion. ${ }^{22}$ Recently, Emmeluth and colleagues ${ }^{23}$ demonstrated a significant increase in renal sodium and urodilatin excretion after a selective $2 \%$ increase in sodium concentration in the carotid arteries in conscious dogs. A comparable isotonic volume expansion caused a significantly smaller increase in sodium excretion and no changes in urodilatin excretion. ${ }^{23}$ These findings are supported by the significant correlation between comparable variations in serum sodium (about $1.5 \%$ ) and urodilatin excretion in the present study. Thus, taken together, these results suggest that the release of urodilatin in human beings might be modified by hemodynamics, including stimulation of intracardiac receptors, and by levels of serum sodium.

The mean excretion rate of urodilatin in our patients $(98 \mathrm{fmol} / \mathrm{min}$ ) was threefold to sixfold higher than the values reported from healthy subjects ( 15 to $35 \mathrm{fmol} / \mathrm{min})^{10,22}$ in studies that used a measuring procedure, type of synthetic urodilatin, and antibodies identical to those of the present study. This might suggest that urodilatin release was stimulated postoperatively in our patients, none of whom had renal insufficiency. Renal failure, however, is a frequent complication after cardiac transplantation, a procedure which, theoretically, could interfere with urodilatin release in at least two ways: through the nephrotoxicity of cyclosporine (INN: ciclosporin) and as a result of the severing of major parts of cardiac nervous connections. It is therefore interesting that the administration of urodilatin in the early postoperative phases after heart transplantation appears to improve renal function ${ }^{24}$ or, at least, reduce the duration of hemofiltration and frequency of hemodialysis compared with placebo. ${ }^{25}$ However, at present we do not know whether urodilatin excretion after cardiac transplantation is com- promised or whether patients in whom renal insufficiency develops after $\mathrm{CPB}$ have a suppressed urodilatin release.

In conclusion, results of the present study add further support to the concept of an important role for urodilatin (and a superior role to that of ANF) in the renal regulation of sodium and water excretion, also in patients with very high levels of circulating ANF who have had operations involving CPB.

\section{REFERENCES}

1. Schulz-Knappe P, Forssmann K, Herbst F, Hock D, Pipkorn R, Forssmann WG. Isolation and structural analysis of "urodilatin," a new peptide of the cardiodilatin-(ANP)-family, extracted from human urine. Klin Wochenschr 1988;66:752-9.

2. Forssmann WG, Nokihara K, Gagelmann M, Hock D, Feller $\mathrm{S}$, Schulz-Knappe $\mathrm{P}$, et al. The heart is the center of a new endocrine, paracrine, and neuroendocrine system. Arch Histol Cytol 1989;52(Suppl):293-315.

3. Saxenhofer H, Raselli A, Weidmann P, Forssmann WG, Bub $A$, Ferrari $P$, et al. Urodilatin, a natriuretic factor from kidneys, can modify renal and cardiovascular function in men. Am J Physiol 1990;259:F832-8.

4. Bestle MH, Bie P. Renal effects of urodilatin and atrial natriuretic peptide in volume expanded conscious dogs. Acta Physiol Scand 1993;149:77-83.

5. Hildebrandt DA, Mizelle HL, Brands MW, Hall JE. Comparison of renal actions of urodilatin and atrial natriuretic peptide. Am J Physiol 1992;262:R395-9.

6. Riegger GAJ, Elsner D, Forssmann WG, Kromer EP. Effects of ANP-(95-126) in dogs before and after induction of heart failure. Am J Physiol 1990;259:H1643-8.

7. Villareal D, Freeman RH, Johnson RA. Renal effects of ANF (95-126), a new atria! peptide analogue, in dogs with experimental heart failure. Am J Hypertens 1991;4:508-15.

8. Abassi ZA, Tate J, Hunsberger S, Klein H, Trachewsky D, Keiser HR. Pharmacokinetics of ANF and urodilatin during cANF receptor blockade and neutral endopeptidase inhibition. Am J Physiol 1992;263:E870-6.

9. Gagelmann M, Hock D, Forssmann WG. Urodilatin (CDD/ ANP-95126) is not biologically inactivated by a peptidase from dog kidney cortex membranes in contrast to atrial natriuretic peptide/cardiodilatin ( $\alpha$-hANP/CDD-99-126). FEBS Lett 1988;223:249-54.

10. Drummer C, Fiedler F, König A, Gerzer R. Urodilatin, a kidney-derived natriuretic factor, is excreted with a circadian rhythm and is stimulated by saline infusion in man. J Am Soc Nephrol 1991;1:1109-13.

11. Abassi ZA, Golomb E, Klein H, Keiser HR. Urodilatin: a natriuretic peptide of renal origin. Cardiovasc Drug Rev 1992;10:199-210.

12. Goetz KL. Renal natriuretic peptide (urodilatin?) and atriopeptin: evolving concepts. Am J Physiol 1991;261:F921-32.

13. Humphreys MH. Urodilatin-Renal natriuretic peptide? J Am Soc Nephrol 1991;1:1057-9.

14. Dewar ML, Walsh G, Chiu CJ, Kochamba G, Gutkowska J, Genest $\mathrm{J}$, et al. Atrial natriuretic factor: response to cardiac operation. J Thorac Cardiovasc Surg 1988;96:266-70.

15. Schaff HV, Mashburn JP, McCarthy PM, Torres EJ, Burnett JC. Natriuresis during and early after cardiopulmonary bypass: 
relationship to atrial natriuretic factor, aldosterone, and antidiuretic hormone. J Thorac Cardiovasc Surg. 1989;98:979-86.

16. Goetz K, Drummer C, Zhu JL, Leadley R, Fiedler F, Gerzer $R$. Evidence that urodilatin, rather than ANP, regulates renal sodium excretion. J Am Soc Nephrol 1990;1:867-74.

17. Roy RC. Does isoflurane really preserve baroreflex responsiveness better than halothane or enflurane? Anesthesiology $1984 ; 61: 482-3$.

18. Sehested J, Thomas F, Thom M, Schifter S, Regitz V, Sheikh $S$, et al. Level and diurnal variations of hormones of interest to the cardiovascular system in patients with heart transplants. Am J Cardiol 1992;69:397-402.

19. Drummer C, Fiedler F, Bub A, Kleefeld D, Dimitriades E, Gerzer R, et al. Development and application of a urodilatin (CDD/ANP-95-126)-specific radioimmunoassay. Pflugers Arch 1993;423:372-7.

20. Kaever V, Resch $\mathrm{K}$. Are cyclic nucleotides involved in the initiation of mitogenic activation of human lymphocytes? Biochim Biophys Acta 1985;846:216-25.
21. Drummer C, Gerzer R, Heer M, Molz B, Bie P, Schlossberger $\mathrm{M}$, et al. Effects of an acute saline infusion on fluid and electrolyte metabolism in humans. Am J Physiol 1992; 262:F744-54.

22. Norsk P, Drummer C, Johansen LB, Gerzer R. Effect of water immersion on renal natriuretic peptide (urodilatin) excretion in humans. J Appl Physiol 1993;74:2881-5.

23. Emmeluth C, Drummer C, Gerzer R, Bie P. Roles of cephalic $\mathrm{Na}^{+}$concentration and urodilatin in control of renal $\mathrm{Na}^{+}$excretion. Am J Physiol 1992;262:F513-6.

24. Hummel M, Kuhn M, Bub A, Mann B, Schneider B, von Eickstedt K-W, et al. Urodilatin, a new therapy to prevent kidney failure after heart transplantation. J Heart Transplant 1993;12:209-18.

25. Brenner P, Meyer M, Reichenspurner H, Meiser B, Müller $\mathrm{R}$, Mentz $\mathrm{P}$, et al. Significance of prophylactic urodilatin (INN: ularitide) infusion for the prevention of acute renal failure in patients after heart transplantation. Eur J Med Res 1995/96;1:137-43. 